\title{
How useful could Arabic documentary sources be for reconstructing past climate?
}

\section{Fernando Domínguez- Castro, ${ }^{1}$ José Manuel Vaquero, ${ }^{1,2}$ Manuela Marín, ${ }^{3}$ María Cruz Gallego ${ }^{1}$ and Ricardo García-Herrera ${ }^{4}$ \\ 'Department of Physics, University of Extremadura, Spain \\ ${ }^{2}$ CGUL-IDL, University of Lisbon, Portugal \\ ${ }^{3}$ CSIC, National Research Council, \\ Madrid, Spain \\ ${ }^{4}$ AEMET, Agencia Estatal de \\ Meteorología, Madrid, Spain}

\section{Introduction}

Trees, corals, ice cores and documentary evidence provide high-resolution proxies that allow past climate to be reconstructed (Jones et al., 2009). Documentary evidence includes all forms of written historical information about past climate or weather, but its use for climate reconstruction is restricted to locations for which there is a rich documentary legacy. Several climate analyses and reconstructions have been undertaken using documentary evidence from Europe (Brázdil et al., 2005; 2010), North and South America (Dupigny-Giroux and Mock, 2009; Prieto and García-Herrera, 2009; Neukom et al., 2010), Asia (Ge et al., 2005; 2010; Aono and Kazui, 2008; Hirano and Mikami, 2008) and oceanic areas (García-Herrera et al., 2005). The Islamic World is a region for which such sources could also be used to reconstruct past climate, as indeed they have been widely used for astronomy and geophysics. Astronomers have used the observations made by Arab astronomers for centuries, with some remarkable examples. Historical eclipse observations, recorded by various ancient and mediaeval cultures including Arabs, have enabled changes in the Earth's rate of rotation to be monitored with fair precision as far back as around 700 AD (Stephenson, 2003). Rada and Stephenson (1992) catalogued meteor showers using mediaeval Arab chronicles and Ahn (2003) investigated the spatial dis- orbit of the Earth from the tenth to the fourteenth centuries using chronicles from Korea, Japan, China, Arabia and Europe. Documentary sources from Iberia have been used to identify and date such astronomical phenomena as eclipses and comets (Vernet, 1982), naked-eye sunspots (Vaquero and Gallego, 2002) and aurora sightings (Vaquero and Gallego, 2001). The work of Basurah (2006) provides descriptions for 18 aurora displays on various dates at low latitudes in the Mediterranean area taken from Islamic chronicles (ninth to sixteenth centuries). In seismology, Arabic chronicles were extensively used to prepare the Seismic Catalogue of the Iberian Peninsula (Martínez and Mezcua, 2002) and to study seismic activity in Syria and Palestine (Ambraseseys, 2005).

However, the use of these sources to recover climate information is, to the best of our knowledge, still very limited (Bulliet, 2009; Jones et al., 2009). Here we describe a preliminary inquiry based on Arabic documentary sources from Iraq. We would stress the antiquity of the documents used, with dates in the period 816-1009 AD. The sources consulted are Arabic chronicles that narrate the social, political and religious history of different regions in a form very characteristic of Arab culture.

\section{Historical context}

With the advent of the Abbasids (second dynasty of Islam) in $750 \mathrm{AD}$, the centre of the political and military balance in Islam moved eastwards from Damascus to Mesopotamia, the land between the two rivers, the Euphrates and the Tigris, i.e., Iraq (Figure 1(a)). In 762, Abu Ja'far al-Mansur, the second Abbasid Caliph, founded the city of Baghdad, establishing it as the capital of an empire stretching from India to the shores of the Atlantic. Baghdad soon became the most flourishing city of its time, a centre of international trade and agricultural development, attracting a growing population and reaching its peak during the eighth to ninth centuries (Gabrieli et al., 1988; Micheau, 2000; 2008; Kennedy, 2006). The primitive core of the city was established on the right bank of the Tigris, but it soon expanded to the left bank to cover a huge area of land, absorbing countless small hamlets in the surrounding space (Figure 1(b)).

The reasons for al-Mansur's choosing this particular point in Iraq to establish the new Abbasid capital were discussed in contemporary historical accounts, with great importance given to the fact that Baghdad lies where the Euphrates and Tigris come closest to each other (Lassner, 1970; Bennison, 2009). But Arab historians also stress the quality of the climatic conditions in the area. Al-Ya'qubi, who wrote a renowned geographical treatise in 891 , says of the city that it had no rival in the world because water was plentiful and the climate was very hot in summer, very cold in winter and mild in spring and autumn. These climatic conditions, he assures his readers, favour an excellent agricultural production, thus allowing the growth of the population and general prosperity (Al-Ya`qubi, 1891).

Several of the points stressed by Al-Ya`qubi will reappear in the documentary evidence to be presented below. Of particular interest are the references to the abundance of water and especially to the great network of canals connecting the two rivers which drained eastwards into the Tigris and created a complex system of irrigation and water supply for the ever-growing city (Le Strange, 1900; 1905) (Figure 1(b)). These uncovered canals carried flowing water throughout the year (Al-'Ali, 1985), thus requiring considerable care and expense for their maintenance.

A last note in these comments on the historical context of the data to be described below may be required for readers unfamiliar with the traditional way of life in Baghdad that survived well into the twentieth century. Al-Ya'qubi writes that summers in the city are 'very hot', and as a consequence in summer people spend the hottest parts of the day in cooler rooms below ground called sirdab in Arabic. In contrast, when night falls, the whole family moves to the terraced roofs, now the coolest area, where beds are made up for the family to sleep.

\section{The documentary sources}

Archival records or documents from Islamic history during the Middle Ages (seventh to 
(a)

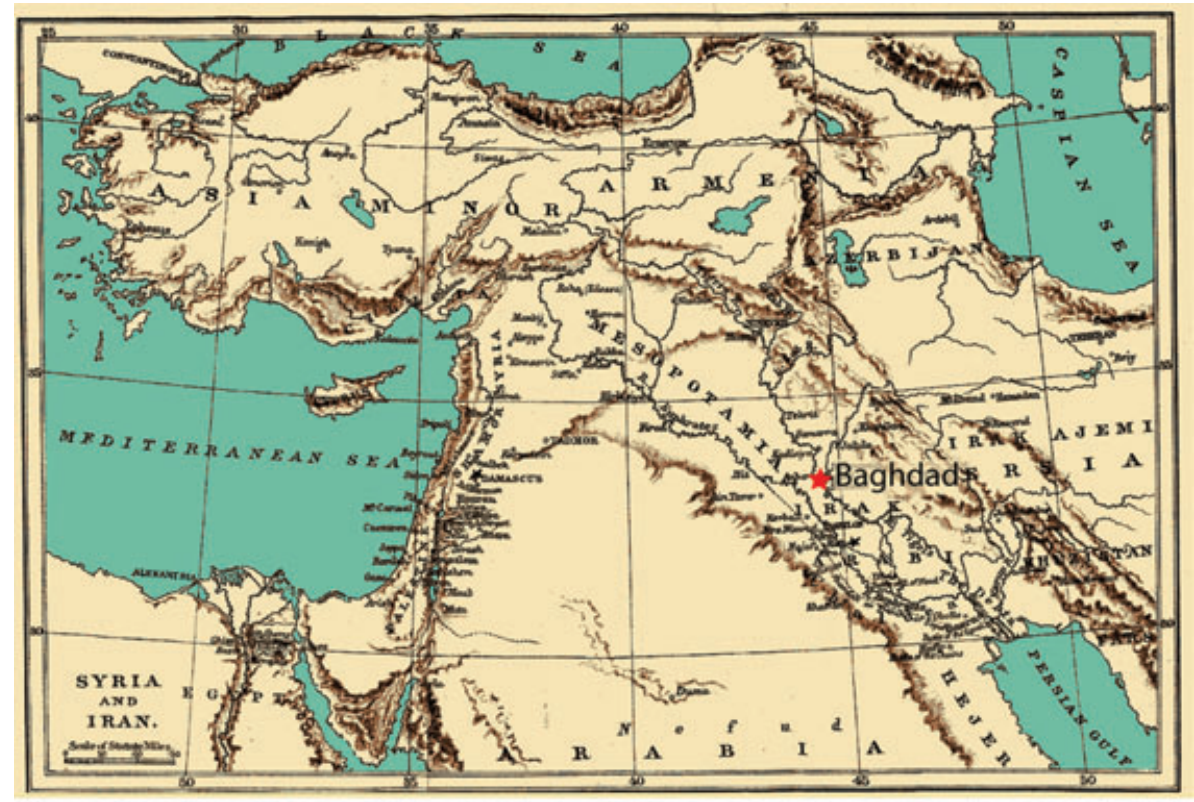

(b)

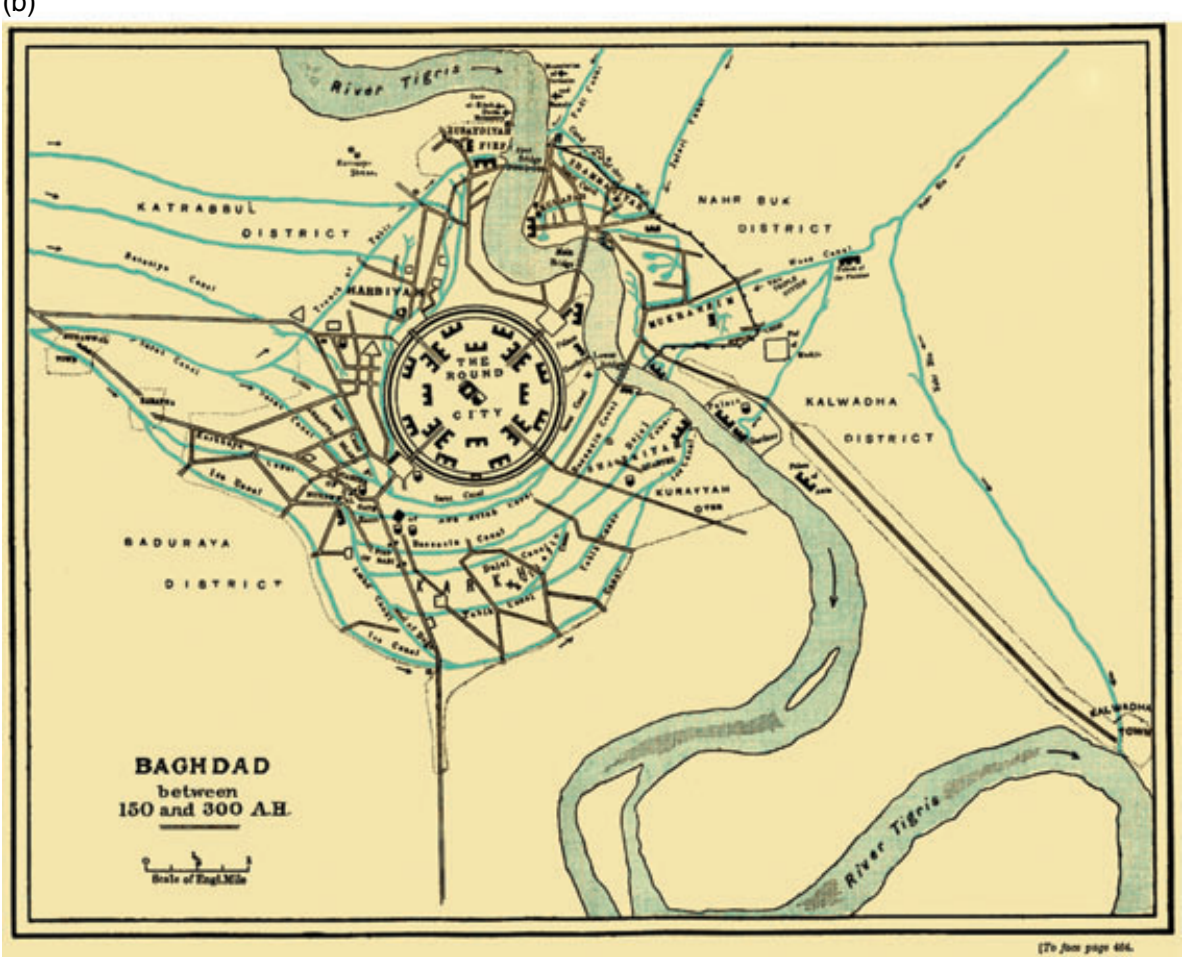

Figure 1. (a) Location of the study area (modified from Muir, 1883). (b) Baghdad map between 770 and $910 A D$ (from Muir, 1883).

fourteenth centuries) have been poorly preserved. This does not mean that Arabs and Muslims in general were not inclined to keep the records of their common past. On the contrary, there was a tradition of historiography in place from very early times, first in order to retrieve and record the 'Prophetic Times' of the life and deeds of Muhammad, and secondly to register how the community he had founded was trying to follow his path and establish a new and universally-minded way of life. This written record, called ta'rikh ('history') depended as much on documents as it did on the oral tradition which had been a paramount characteristic of Arab culture (Humphreys, 2000; Robinson, 2003).

The replacement of papyri by paper ficlition of the word (not only for administrative purpose a negative consequence. Paper is a far more fragile material than the papyri or parchment which had been used previously, and this explains to some extent why there are no extant archives from the Abbasid period.
Other factors contributed to the loss of the official records of such a highly bureaucratized state as was the Abbasid Caliphate. From the ninth century on, civil strife and military invasions brought great destruction to Baghdad. This reached its highest point when, in 1258, the Mongols put a violent end to the Abbasid Caliph. According to the historical traditions concerning this event, the waters of the Tigris flowed alternately red (from the blood of the killed inhabitants) and black (from the ink of the plundered manuscripts thrown into the river).

But not all was lost. The thriving tradition of Islamic historiography soon began to record the Annals of the Caliphs, successors of the Prophet and guides of the Muslim community. Every reign was recorded with its events ordered chronologically, year after year. For that kind of historical record, Muslim authors had to have access to archival materials and/or to the people's oral memories.

From 923, date of the death of the great Arab historian al-Tabari, through to the nineteenth century, annalistic chronicles dominated Arab historiography (Humphreys, 2000). Many of the later authors simply copied their predecessors and the original sources are frequently lost, so modern historians face narratives separated from the events they describe by a considerable chronological gap.

In analysing Arabic sources, the influence of the use of a lunar calendar must be considered carefully. The Islamic or Muslim calendar (also called Hijri) is used in many predominantly Muslim countries (and by Muslims everywhere to celebrate Islamic holy days). This calendar has 12 lunar months in a year of about 354 days. Each month has either 29 or 30 days, but usually in no precisely discernible order because the first day of each month was the day (beginning at sunset) of the first sighting of the lunar crescent (the hilal) shortly after sunset. If the hilal was not observed immediately after the 29th day of a month then the day that began at that sunset was the 30th. Thus, the Islamic dates in historical sources suffer from a degree of uncertainty. Indeed, on occasions, two cities which were close to each other have different dates for the same event. Moreover, the Islamic year will not correspond with a Gregorian year (for instance, the year $197 \mathrm{H}$ corresponds to the dates 12 September 812 AD to 31 August 813 AD).

Arabic historiography, as in the texts compiled and used for this communication (Table 1), could well represent a useful source for the kind of events that are recorded in annals and which are related to meteorological and natural conditions. While the narration of human deeds in such works is obviously subject to personal, political and religious interpretations, and indeed bias, nothing of the kind hinders the accurate recording of heavy rains, extreme cold or a solar eclipse. 
Table 1

Sources consulted.

Title Author Remarks

Ta'rikh al-rusul wa-l-muluk (History of the

Prophets and Kings)

Ta'rikh al-Mawsil (History of Mosul)

Ta'rikh sini muluk al-ard wa-l-anbiya' (History of the Annals of the Kings of the Earth and of the Prophets)

Al-Juz' al-thamin min ta'rikh Abi l-Husayn Hilal $b$. al-Muhassin b. Ibrahim al-Sabi al-Katib (Eight volumes of the History by Hilal al-Sabi)

Takmilat ta'rikh al-Tabari (Completion of the history by al-Tabari)

Al-Muntazam fi ta'rikh al-umam (The WellArranged History of the Nations)

Al-Kamil fi l-ta'rikh (The Complete History)

Al-Bidaya wa-l-nihaya (The Beginning and the End)

Al-Nujum al-zahira fi muluk Misr wa-l-Qahira (The Brilliant Stars, on the History of the Kings of Egypt and Cairo)

Ta'rikh al-khulafa' (The History of the Caliphs)
al-Tabari (d. 913)

Hamza al-Isfahani

(d. 961)

Covers the whole history of Islam until the author's death. Provides interesting information on Iraq, especially Baghdad, during the ninth century.

Centred around the political annalistic history of Mosul, it is one of the best historical records of this time.

Hilal al-Sabi (d. 1056) Hilal was well placed to have access to official records (Director of the Chancery of the Buwayhid princes). It is a pity that only a small part of this chronicle is extant.

al-Hamadhani A continuation of al-Tabari's chronicle.

(d. 1119)

Ibn al-Jawzi, (d. 1200)

Ibn al-Athir (d. 1233) Coincides frequently with that of Ibn al-Jawzi.

Ibn Kathir (d. 1373) The author was a well-known commentator of the Qur'an as well as a historian and traditionist.

Ibn Taghri Birdi (d. 1470)

Covers Egyptian history from the Arab conquest (seventh century) to 1469 .

al-Suyuti (d. 1505)
Author enormously prolific on all kinds of subjects,

including annalistic history.

Table 2

Main events extracted from the sources consulted. For each source we provide the type of event and date(s) of occurrence (Arabic calendar).

\begin{tabular}{|c|c|c|c|c|c|c|c|c|}
\hline Source & Drought & Flood & Rain & Hail & Cold & Hot & Wind & Locust \\
\hline Al-Tabari & $\begin{array}{c}231,232,245 \\
281,284\end{array}$ & 291 & 249,285 & - & 241,289 & - & 285 & - \\
\hline Al-Azdi & - & - & - & - & 216,232 & - & - & - \\
\hline Ibn Kathir & $\begin{array}{l}245,296,297 \\
348,359,377\end{array}$ & 328 & 249, 319 & - & $\begin{array}{c}241,308,388 \\
389\end{array}$ & $298,323,331$ & $\begin{array}{c}298,314,378 \\
389,398\end{array}$ & $311,344,348$ \\
\hline Ibn al-Athir & $\begin{array}{c}348,352,358 \\
377\end{array}$ & 291, 378 & $249,319,378$ & & $\begin{array}{c}241,296,314, \\
398\end{array}$ & 298 & $298,378,398$ & $311,342,348$ \\
\hline Ibn Taghri Birdi & $242,245,358$ & 328 & - & - & 296,314 & - & $243,314,378$ & 347 \\
\hline Al-Suyuti & 281 & - & 285 & - & 314 & - & $243,285,378$ & - \\
\hline Ibn al-Jawzi & $\begin{array}{c}297,329,358, \\
359,377\end{array}$ & 328 & - & $335,350,354$ & $\begin{array}{c}289,290,308, \\
314,388,389 \\
398\end{array}$ & 298, 331 & 298, 389, 398 & $\begin{array}{c}311,331,344 \\
347,360\end{array}$ \\
\hline Al-Hamadhani & 358 & - & - & - & 308 & - & - & 331 \\
\hline $\begin{array}{l}\text { Hamza } \\
\text { al-Isfahani }\end{array}$ & - & - & - & - & 330,332 & - & - & - \\
\hline Al-Sabi & - & - & - & - & 389,392 & - & 389 & - \\
\hline Summary & $\begin{array}{c}231,232,242, \\
\mathbf{2 4 5}, \mathbf{2 8 1}, 284, \\
296, \mathbf{2 9 7}, 329 \\
\mathbf{3 4 8 ,} 352, \mathbf{3 5 8} \\
\mathbf{3 5 9}, \mathbf{3 7 7}\end{array}$ & $\begin{array}{c}\text { 291, 328, } \\
378\end{array}$ & $\begin{array}{c}249,285 \\
319,378\end{array}$ & $335,350,354$ & $\begin{array}{c}216,232, \mathbf{2 4 1} \\
\mathbf{2 8 9}, 290, \mathbf{2 9 6}, \\
\mathbf{3 0 8 ,} \mathbf{3 1 4 ,} 330 \\
332, \mathbf{3 8 8}, \mathbf{3 8 9} \\
392, \mathbf{3 9 8}\end{array}$ & $\begin{array}{c}\text { 298, 323, } \\
331\end{array}$ & $\begin{array}{c}243,285 \\
298,314, \\
378,389 \\
398\end{array}$ & $\begin{array}{c}\mathbf{3 1 1}, \mathbf{3 3 1}, \\
342,344, \\
347,348 \\
360\end{array}$ \\
\hline
\end{tabular}

\section{Meteorological information extracted from the texts}

Table 2 shows a summary of the climatic events identified from the sources consulted.
Irrespective of the original resolution provided in the text, they have all been identified by the year of occurrence. Many events were recorded in different sources - for example, the drought of $358 \mathrm{H}$ appears in Ibn al-Athir,
Ibn Taghri Birdi and Ibn al-Jawzi. This is merely because the later chronicles are based on the earlier ones, as explained above.

Of all the information about meteorological phenomena in the geographical area of 
Table 3

Texts detailing notably cold spells in Baghdad and nearby regions reported by Arabic chroniclers.

COLD SPELL 1 (February 831-February 832)

Cold was very intense in the winter of this year throughout al-Jazira and Iraq (northern and southern parts of today's Iraq). Very difficult circumstances affected the population. (Al-Azdi, 1967, Ta'rikh al-Mawsil, p. 406)

COLD SPELL 2 (April 847)

Cold was very intense this year in the month of April, to the point that water froze on the fifth day of this month. (Al-Tabari, 1879-1901, Ta'rikh al-rusul wa-I-muluk, XII, p. 1363)

\section{COLD SPELL 3 (May 855-May 856)}

This year winds from the country of the Turks affected many people, who died because they caught the coolness of the winds and suffered from the cold. The winds reached Sarakhs, Nisabur, Hamadhan, al-Rayy, and even Hulwan. (Ibn al-Athir, 1966, al-Kamil fi l-ta'rikh, VII, pp. 79-80)

\section{COLD SPELL 4 (November 902)}

This year, on the 9th of the month of dhu I-hijja (14 November, 902), people in Baghdad were attending the afternoon prayer wearing summer gowns. At this time, a wind from the north blew, cooling the atmosphere to the point that people were obliged to sit around fires to keep warm, wearing winter clothes. Cold intensified until water froze. (Al-Tabari, 1879-1901, Ta'rikh al-rusul wa-I-muluk, XIII, p. 2209)

COLD SPELL 5 (January 903)

On 24 January, snow fell in Baghdad from the morning till the afternoon. (Ibn al-Jawzi, 1938, al-Muntazam fi l-ta'rikh, Vl, p. 39)

\section{COLD SPELL 6 (December 908-January 909)}

This year snow fell heavily in Baghdad, from the morning till the afternoon. There were four fingers of snow over the ground, and cold was intense. Water, vinegar, eggs, and unguents froze. The cold killed palm-trees and most of the fruit-trees. (Ibn al-Athir, 1966, Al-Kamil fi l-ta'rikh, VI, p. 135)

In January of this year, snow fell in Baghdad from the morning till the afternoon, and it stayed for days on the ground without melting away. (Ibn Taghri Birdi, 1992, Al-Nujum al-zahira, III, p. 165)

On Saturday 26th, Rabi' I (23 December, 908) snow fell heavily in Baghdad, to the point that four fingers of snow accumulated on the roofs. This was very unusual in Baghdad. But the year had not ended when people made the prayer for rain, which was late in arriving. (Ibn Kathir, 1978, al-Bidaya wa-I-nihaya, XI, p. 107)

$$
\text { COLD SPELL } 7 \text { (July 920) }
$$

In July of this year, the weather became so cold that people left the roof terraces (where they usually slept) and wrapped themselves in blankets. (Al-Hamadhani, 1959, Takmilat ta'rikh al-Tabari, p. 31)

In July of this year, the weather became so cold that people left the roof terraces (where they usually slept) and wrapped themselves in blankets. Later on, in winter, a strong hail poured down, damaging palm-trees and other trees. There was also a great snowfall. (Ibn al-Jawzi, 1938, Al-Muntazam fi ta'rikh al-umam, VI, p. 156)

In July of this year there was a severe cold, which affected the palm-trees. (Ibn Kathir, 1978, Al-Bidaya wa-I-nihaya, VI, p. 131)

\section{COLD SPELL 8 (December 926)}

On 7 December, there was a great snowfall in Baghdad. Six days before that, the weather had become very cold, and after the snow, it was even more cold, being so extreme that most of the palm-trees in Baghdad and its rural area were ruined, as well as other trees, such as citron, fig, and lotus. Sherbet and rose-water froze, as well as vinegar. The great water-canals from the Tigris in Baghdad were frozen, as was the greater part of the river Euphrates on the region of al-Raqqa. The whole of the river Tigris was frozen at Mosul, so that ridden animals could cross over it. The scholar known as Abu Zakariya sat in the middle of the Tigris, on the ice, and gave there lessons of Prophetical Tradition. Afterwards the cold subsided thanks to the south winds and copious rains. (Ibn al-Jawzi, 1938, Al-Muntazam fi ta'rikh al-umam, VI, p. 201)

This year the Tigris was frozen at Mosul, from Balad up to al-Haditha, and ridden animals could cross over it, so cold was it. (Ibn al-Athir, 1966, Al-Kamil fi l-ta'rikh, VIII, p. 167)

This year the Tigris was frozen at Mosul, so that ridden animals could cross over it. There were also many snow-falls in Baghdad. (lbn Taghri Birdi, 1992, Al-Nujum al-zahira fi muluk Misr wa-l-Qahira, III, p. 242)

This year the Tigris was frozen at Mosul, so that ridden animals could cross over it, and this was never witnessed before. (Al-Suyuti, 1992, Ta'rikh al-khulafa', p. 408)

$$
\text { COLD SPELL } 9 \text { (November 941) }
$$

There was a great fall of snow on the 10th of Aban (2 November, 941). People had never witnessed before snow in Isfahan during this month. (Hamza al-Isfahani, 1961, Ta'rikh sini muluk al-ard wa-l-anbiya', p. 149)

$$
\text { COLD SPELL } 10 \text { (March 944) }
$$

In 332/944, people woke up on the morning of Nayruz (21 March, 944) to a great fall of snow which required sweeping away. Such a thing was never seen before in the spring, and trees were damaged in Isfahan, as they were in all the Eastern regions. As a consequence, people had to do without fruits this year. (Hamza al-Isfahani, 1961, Ta'rikh sini muluk al-ard wa-l-anbiya', p. 149)

\section{COLD SPELL 11 (December 998)}

On Thursday, the 10th of dhu I-hijja (3 December, 998), cold was extreme, and water was frozen completely, as was never experienced before. Even the cisterns in public baths were frozen, and also the urine of riding beasts and horses, and grape must. (Ibn al-Jawzi, 1938, Al-Muntazam fi ta'rikh al-umam, VII, p. 202) 
This year the cold was extreme, with clouds covering the sky and continuous strong winds. Thousands of palm-trees in the rural areas of Madinat al-salam (Bahgdad) perished, and those who escaped were weakened and needed some years to recover their previous loftiness and their whole body. (Hilal al-Sabi, 1986, Al-Juz' al-thamin min ta'rikh Abi l-Husayn Hilal b. al-Muhassin b. Ibrahim al-Sabi al-Katib, p. 340)

This year the cold was extreme, with clouds covering the sky and continuous strong winds. Thousands of palm-trees in the rural areas of Baghdad perished, and those who escaped were weakened and needed some years to recover their previous strength. (Ibn al-Jawzi, 1938, Al-Muntazam fi ta'rikh al-umam, VII, p. 206)

\section{COLD SPELL 13 (March 1002)}

On Monday, the fifth day of the month of Jumada l-ula of this year, that is, on 22 March, cold was extreme and water froze. (Hilal al-Sabi, 1986, Al-Juz' al-thamin min ta'rikh Abi l-Husayn Hilal b. al-Muhassin b. Ibrahim al-Sabi al-Katib, p. 418)

\section{COLD SPELL 14 (November 1007)}

This year, on Wednesday, the 11th of rabi' I (25 November, 1007), there was a great fall of snow in Baghdad. Its height on the surface of the earth was of a dhira' $(\mathrm{c} .80 \mathrm{~cm})$ or a dhira' and a half, depending on the places. The snow stayed for a week, without melting away. People threw it from their house roofs to the streets and alleys with shovels. Then the snow began to melt, but it remained in some places for twenty days. This snowfall reached Tikrit, and letters arrived from Wasit informing of snow falling between the marshes (a-Batiha) and Basra, Kufa, Abadan, and Mahruban. (Ibn al-Jawzi, 1938, Al-Muntazam fi ta'rikh al-umam, VII, p. 237)

This year, in the month of rabi' I (November 1007), there was a great fall of snow in Baghdad, Wasit, Kufa, and the marshes (bata'ih), up to Abadan. In Baghdad, the snow reached a height of nearly a dhira $(\mathrm{c} .80 \mathrm{~cm})$, and it stayed in the streets for nearly 20 days. (Ibn al-Athir, 1966, Al-Kamil fi l-ta'rikh, IX, p. 208)

Baghdad, the cold spells that occurred in the third and fourth Islamic centuries (ninth and tenth centuries in the Gregorian calendar) stand out for their frequency. Table 3 lists all the different texts that we found in the chronicles describing fourteen periods of notably cold weather: five in winter, four in autumn, two in spring and one in summer. We also found two references to cold weather for an entire year. Some texts indicate temperatures below $0^{\circ} \mathrm{C}$ during these periods, i.e., snowfalls (six), frozen liquids (six) and frozen rivers (one). (Figure 2).

Snowfalls: Six snowfalls were recorded (Table 3: cold spells 5, 6, 8, 9, 10, 14). Two of them give a measure of the quantity of snow accumulated: on 23 December 908 when four fingers of snow accumulated on the roofs and on 25 November 1007 when its height on the surface of the earth was a dhira' $(\mathrm{c} .80 \mathrm{~cm})$ or a dhira' and a half. This event also provides information about how long the snow remained without thawing: the snow stayed for a week, without melting.... Then the snow began to melt, but it remained in some places for twenty days. Another snowfall, interesting for its late date, was on 21 March 944: Such a thing was never seen before in the spring. During the modern instrumental period, only one snowfall has been recorded. This was on 11 January 2008, a day which became famous in Baghdad because nobody had ever seen snow in the city before (BBC, 2008; REUTERS, 2008). The mean temperature of that day was $3^{\circ} \mathrm{C}$, and the snow mostly melted when it touched the ground. Since all the documented snowfalls seem more intense than the 2008 event, we think that the temperatures during historical snowfalls were around $0^{\circ} \mathrm{C}$.

Frozen liquids: Specifications of which fluids froze were included in the descriptions of some of these events. This was probably used in those times to provide an estimate of the intensity of the cold. However, it is very difficult to accurately infer temperatures from these descriptions because many factors affect freezing points. For example, the freezing point of animal urine (cold spell 11) depends directly on the concentrations of dissolved salts, and ranges approximately between $-0.45^{\circ} \mathrm{C}$ and $-2.4^{\circ} \mathrm{C}$. The case is similar with vinegar (cold spells 6 and 8) since its freezing point depends on the concentration of acetic acid: vinegar with a concentration of $5 \%$ in volume (the commonest today) freezes at $-2^{\circ} \mathrm{C}$. Grape must (cold spell 11) also has uncertainties because the freezing points of different grape varieties vary greatly: for example, the must of the Mania variety freezes at $-2.17^{\circ} \mathrm{C}$. References to freezing water (cold spells $2,4,6,8,11,13$ ), regardless of its quality, seem easier to interpret. However, one description states that the cisterns in public baths were frozen (cold spell 11), so the temperature inside the cistern must have been below $0^{\circ} \mathrm{C}$. The open air temperature is difficult to estimate, however, since the thermal insulation of the public bath and the cistern are not known. This situation also applies to all liquids which we can assume to have been inside houses.

Frozen rivers: References to frozen rivers and canals imply below-freezing temperatures for a sustained period. These circumstances only occurred in the harshest cold wave of December 926 (cold spell 8): The great water-canals from the Tigris in Baghdad were frozen, as was the greater part of the river Euphrates in the region of al-Raqqa. The whole of the river Tigris was frozen at Mosul, so that ridden animals could cross over it. The Arab text is referring to major canals such as the nahr 'Isa connecting the Tigris to the Euphrates through the southern parts of the city, not to the many smaller canals which branch off from it or other similar constructions which served the many

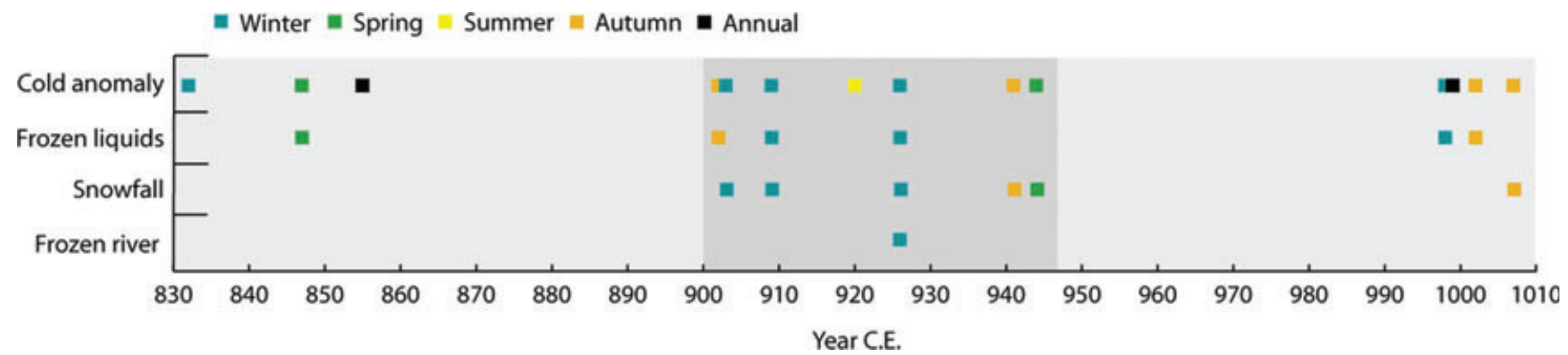


neighbourhoods of Baghdad and its rural surroundings. The choice of words by the Arab text (the great water-canals) is intended to portray the intensity of the cold spell in 926, but it also reveals the hierarchy of the system of public works ensuring the distribution of water in Baghdad, both for human consumption and for agricultural purposes.

\section{Investigating the cold periods}

In a search for negative anomalies in the recent instrumental period, we examined the daily temperature records for the Baghdad airport station $\left(33.2^{\circ} \mathrm{N} 44.2^{\circ} \mathrm{E}\right)$ (http://www. ncdc.noaa.gov/oa/climate/ghcn-daily/). This series started in 1954, but has many gaps. Only 19 winters (December-February) have sufficient daily data coverage (1954, 1955, 1958, 1963-1968, 1973-1980, 1990, 2008). These show only two days with mean temperature below $0^{\circ} \mathrm{C}: 19$ and 20 January 1964 $\left(-1{ }^{\circ} \mathrm{C}\right.$ and $-1.2^{\circ} \mathrm{C}$, respectively).

During the 193 years (third and fourth Hijra centuries; 816-1009 AD) which were covered by the documentary sources that we studied, there were 10 cold spells with temperatures below $0^{\circ} \mathrm{C}$. This implies a return period of 19.3 years - although six of these events appear during a 42-year period between 902 and 944 . Furthermore, this period includes the sharpest cold spell when the Tigris and Euphrates froze (December 926). Thus, the frequency of cold spells recorded during the first half of the tenth century has no analogue in the instrumental record, suggesting that the winters in that period were colder than both the contiguous decades and current times. Few temperature reconstructions cover the period studied and none are located close to the study area, but hemispheric reconstructions (e.g., Mann and Jones, 2003; Briffa et al., 2004; Cook et al., 2004; Moberg et al., 2005; Hegerl et al., 2006; D'Arrigo et al., 2006) agree on a relative minimum centred in the first half of the tenth century, immediately before the Mediaeval Warm Period.

The notably cold July 920 deserves special mention. As already described, the picture of typical summer nights in Baghdad is one of people migrating to terrace roofs for their relative comfort in hot weather. This can help us understand how Arab chroniclers describe the extreme and unexpected cool spells that befell the city in July 920: blankets were sought and people left their roofs to sleep inside. A notable cool spell in July, or at least a fall in temperature making it difficult to sleep on a terrace roof, was indeed an extraordinary event. The recommended temperature range for sleep is $18-22^{\circ} \mathrm{C}$. We can thus at least assume that on those nights of July 920 the temperature was below $18^{\circ} \mathrm{C}$. Since the mean July daily minimum temperature during the instrumental period is $26^{\circ} \mathrm{C} \pm 1.8 \mathrm{deg} \mathrm{C}$, we may estimate a negative anomaly of up to 9 $\operatorname{deg} C$ during July 920, depending on how many days people needed to sleep inside. The greatest July anomaly in the instrumental series was $-3.1 \mathrm{degC}(1974 \mathrm{AD})$.

A possible explanation for this major temperature deviation might have been some large-scale volcanic eruption during the previous year. Although there is no volcanic eruption with a high VEI (Volcanic Explosivity Index) in the databases (http://www.volcano.si.edu/) for the year 919, one cannot reject this possibility since many eruptions in those databases are dated with large uncertainties. For example, the volcano Ceboruco in Mexico is listed as erupting with VEl equal to 6 in the year $930 \pm 200$ (Sieron and Siebe, 2008) and the Guagua Pichincha (Ecuador) had an eruption with VEl 5 dated to $910 \pm 100$ (Barberi et al., 1992). However, we found evidence for an unusually cold summer in 920 in the tree-ring reconstruction of Linderholm and Gunnarson (2005) for Sweden: this gave a deviation of $-1.9 \mathrm{deg} C$ relative to the two-millennia summer mean. These coincidences are not enough to confirm the eruption hypothesis, and additional work with other sources would be required to evaluate the spatial extent of this anomaly and any association with such an eruption.

\section{Final comments}

The use of Arabic documentation to study pre-instrumental climate may have major relevance due to the geographical distribution of Arab-Islamic culture. We have described here a preliminary analysis with chronicles from Iraq only.

This first exercise has shown that these sources are subject to the same caveats as those of other documentary sources, such as the difficulty of interpreting secondary sources. There was an additional uncertainty in the present sources' use of a lunar calendar to date the events (Table 1 ).

In general, the Arab sources consulted in the present work had only sparse references to climate. Their main subjects were chronicles of politics and religion, with the climate being part of the background. While some authors were notably sensitive to climatic events, e.g., the works of Ibn Kathir, Ibn alAthir and Ibn al-Jawzi have more than 20 references each, other authors such as Hamza al-Isfahani, Hilal-al-Sabi and alHamadhani include only 2 or 3 climate references.

Although the sources studied are not enough to produce series of climatic variables, they do show that in Baghdad the first half of the tenth century had a greater frequency of significant climate events and more intense cold than today, and probably also than the ninth century and the second half of the tenth century. Particularly interesting during this period is the cold spell in July 920. We have here proposed a hypothesis of a major volcanic eruption to explain this unusual phenomenon, although more work is necessary to confirm this idea.

This first approach to using Arabic sources for climate reconstruction purposes has made it clear that there is a need for the collaboration of Arabists, historians and climatologists to overcome the methodological problems that we have described. The use of the original Arab documentation is crucial for climatological studies of this period, since we have found the reliability of translations to be very limited. On occasions, we have encountered clearly doubtful dates (typographical errors) or difficult-tounderstand translations narrating astronomical or meteorological phenomena.

In summary, the involvement of historians who are experts in Arabic history, together with increased data density, would make it possible to extract robust climate information from these sources. This is indeed the aim of the project 'Historical Climatology of the Middle East based on Arabic sources back to 800 AD' funded by the German Research Foundation.

\section{Acknowledgements}

This research was supported by the Spanish Ministry of Science and Innovation (project AYA2008-04864/AYA) and the Spanish Ministry of the Environment, Rural and Maritime Affairs (project 'Salvà-Sinobas' ref. 200800050083542).

\section{Arabic sources consulted}

Al-Azdi. Ta'rikh al-Mawsil, Al-Majlis al-A`la li--Shu'un al-Islamiyya, Cairo, 1967.

Al-Hamadhani. Takmilat ta'rikh al-Tabari, Beirut, 1959.

Hilal al-Sabi, Al-Juz' al-thamin min ta'rikh Abi I-Husayn Hilal b. al-Muhassin b. Ibrahim al-Sabi al-Katib, Al-Muthanna Library, Baghdad, 1986.

Al-Suyuti. Ta'rikh al-khulafa', 'Izz al-din, Beirut, 1992.

Al-Tabari. Ta'rikh al-rusul wa-l-muluk, E. J. Brill, Leiden, 1879-1901.

Hamza al-Isfahani. Ta'rikh sini muluk al-ard wa-l-anbiya', Maktabat al-Hayat, Beirut, 1961.

Ibn al-Athir. al-Kamil fi l-ta'rikh, Dar Sadir, Beirut, 1966.

Ibn al-Jawzi. al-Muntazam fi l-ta'rikh, Da'irat al-Ma`arif al-'Uthmaniyya, Hyderabad, 1938. Ibn Kathir. al-Bidaya wa-I-nihaya, Dar al-Fikr, Beirut, 1978.

Ibn Taghri Birdi. Al-Nujum al-zahira fi muluk Misr wa-I-Qahira, Dar al-Kutub al-'Ilmiyya, Beirut, 1992. 


\section{References}

Ahn S. 2003. Meteors and showers a millennium ago. Mon. Not. R. Astron. Soc. 343: 1095-1100.

Al-Ali SA. 1985. Bagdad madinat alsalam. Insha' 'u-ha wa-tanzim sukkani-ha fi I-'uhud al-' abbasiyya al-ula. Al-Majma' Al-'IImi Al-'Iraqi: Baghdad, Iraq.

Al-Ya qubi.1891. Kitab al-buldan. De Goeje MJ (ed.). E.J. Brill: Leiden, The Netherlands.

Ambraseseys NN. 2005. The seismic activity in Syria and Palestine during the middle of the 8th century; an amalgamation of historical earthquakes. J. Seismol. 9(1): 115-125.

Aono Y, Kazui K. 2008. Phenological data series of cherry tree flowering in Kyoto, Japan, and its application to reconstruction of springtime temperatures since the 9th century. Int. J. Climatol. 28: 905-914.

Barberi F, Ghigliotti M, Macedonio G, Orellana H, Pareschi MT, Rosi M. 1992. Volcanic hazard assessment of Guagua Pichincha (Ecuador) based on past behavior and numerical models. J. Volc. Geotherm. Res. 49: 53-68.

Basurah HM. 2006. Record of aurora in the Islamic chronicles during 9th-16th centuries. J. Atmos. Sol.-Terr. Phys. 68(8): 937-941.

BBC. 2008. Baghdad wakes up to rare snowfall. http://news.bbc.co.uk/2/ hi/7183881.stm [accessed 14 June 2011].

Bennison AK. 2009. The Great Caliphs. The Golden Age of the 'Abbasid Empire. I.B. Tauris: London, UK.

Brázdil R, Dobrovolný P, Luterbacher J, Moberg A, Pfister C, Wheeler D, Zorita

E. 2010. European climate of the past 500 years: new challenges for historical climatology. Clim. Change 101(1-2): 7-40.

\section{Brázdil R, Pfister C, Wanner $\mathbf{H}$, von}

Storch H, Luterbacher J. 2005. Historical climatology in Europe - the state of the art. Clim. Change 70: 363-430.

Briffa KR, Osborn TJ, Schweingruber FH. 2004. Large-scale temperature inferences from tree rings: a review. Global Planet. Change 40(1-2): 11-26.

Bulliet RW. 2009. Cotton, Climate, and Camels in Early Islamic Iran. A Moment in World History. Columbia University Press: New York, NY.

Cook ER, Esper J, D'Arrigo RD. 2004. Extra-tropical Northern Hemisphere land temperature variability over the past 1000 years. Quat. Sci. Rev. 23(20-22): 2063-2074.

D'Arrigo R, Wilson R, Jacoby G. 2006. On the long-term context for late twentieth century warming. J. Geophys. Res. 111: D03103.

Dupigny-Giroux LA, Mock CJ. 2009. Historical Climate Variability and Impacts in North America. Springer: Dordrecht, The Netherlands, Heidelberg, Germany, London, New York, NY.

Gabrieli F, Alfieri BM, Baffioni C, Bausani A, Stasolla G, Traini R. 1988. Le califat de Bagdad. La civilisation abbâside. Syros-Alternatives: Lausanne, Paris.

García-Herrera R, Können GP, Wheeler DA, Prieto MR, Jones PD, Koek FB. 2005. CLIWOC: a climatological database for the world's oceans 1750-1854. Clim. Change 73(1-2): 1-12.

Ge Q, Zheng JY, Hao ZX, Shao XM, Wang WC, Luterbacher J. 2010. Temperature variation through 2000 years in China: an uncertainty analysis of reconstruction and regional differences. Geophys. Res. Lett. 37: L03703.

Ge $\mathbf{Q}$, Zheng JY, Hao ZX, Zhang PY, Wang WC. 2005. Reconstruction of historical climate in China. High-resolution precipitation data from Qing Dynasty archives. Bull. Am. Meteorol. Soc. 86: 671-679.

Hegerl GC, Crowley TJ, Hyde WT, Frame DJ. 2006. Climate sensitivity constrained by temperature reconstructions over the past seven centuries. Nature $\mathbf{4 4 0}$ : 1029-1032.

Hirano J, Mikami T. 2008. Reconstruction of winter climate variations during the 19th century in Japan. Int. J. Climatol. 28 1423-1434.

Humphreys RS. 2000. Ta'rikh, in The Encyclopaedia of Islam. Bearman PJ, Bianquis Th., Bosworth CE, van Donzel E, Heinrichs WP (eds). E.J. Brill: Leiden, The Netherlands. vol.10.

Jones PD, et al. 2009. High-resolution palaeoclimatology of the last millennium: a review of current status and future prospects. Holocene 19: 3-49.

Kennedy H. 2006. When Baghdad Ruled the Muslim World: The Rise and Fall of Islam's Greatest Dynasty. Da Capo Press: Cambridge, MA.

Lassner J. 1970. The Topography of Baghdad in the Early Middle Ages. Wayne State University Press: Detroit, MI. Le Strange G. 1900. Baghdad during the Abbasid Caliphate. Clarendon Press: Oxford, UK.

Le Strange G. 1905. The Lands of the Eastern. Caliphate, University Press: Cambridge.

Linderholm HW, Gunnarson BE. 2005. Summer temperature variability in central Scandinavian during the last 3600 years. Geogr. Ann. A 87(1): 231-241.

Mann ME, Jones PD. 2003. Global surface temperatures over the past two millennia. Geophys. Res. Lett. 30: 1820.

Martínez JM, Mezcua J. 2002. Catálogo sísmico de la Península lbérica (880 A. C. 1900). Ministerio de Fomento, Dirección General del Instituto Geográfico Nacional: Madrid, Spain.
Micheau F. 2000. Bagdad, in Grandes villes mediterraneennes du monde musulman medieval. Garzin JC (ed.). École française de Rome: Rome, Italy . pp. 87-112.

Micheau F. 2008. Baghdad in the abbasid era: a cosmopolitan and multi-confessional capital, in The City in the Islamic World. Jayyusi SK, Holod R, Petruccioli A, Raymond A (eds). Koninklijke Brill NV: Leiden, The Netherlands . pp. 221-245.

Moberg A, Sonechkin DM, Holmgren K, Datsenko NM, Karlen W. 2005. Highly variable Northern Hemisphere temperatures reconstructed from low and high-resolution proxy data. Nature 433: 613-617.

Muir W. 1883. The Caliphate: Its Rise, Decline, and Fall from Original Sources. Smith, Elder \& Co: London, UK.

Neukom R, et al. 2010. Multiproxy summer and winter surface air temperature field reconstructions for southern South America covering the past centuries. Clima. Dyn. doi:10.1007/s00382-0100793-3

Prieto MR, García-Herrera R. 2009. Documentary sources from South America: potencial for climate reconstruction. Palaeogeogr. Palaeoclimatol. $\mathbf{2 8 1}$ (3-4): 196-209.

Rada SW, Stephenson FR. 1992. A catalogue of meteor showers in medieval Arab chronicles. Q. J. R. Astr. Soc. 33: 5-16.

REUTERS. 2008. Snow falls on Baghdad for first time in memory. http://www.reuters. com/article/idUSL1146182220080111 [accessed 14 June 2011].

Robinson CF. 2003. Islamic Historiography. Cambridge University Press: Cambridge, UK.

Sieron K, Siebe C. 2008. Revised stratigraphy and eruption rates of Ceboruco stratovolcano and surrounding monogenetic vents (Nayarit, Mexico) from historical documents and new radiocarbon dates. J. Volc. Geotherm. Res. 176: 241-264.

Stephenson FR. 2003. Historical eclipses and Earth's rotation. Astron. Geophys. 44(2): 2.22-2.27.

Vaquero JM, Gallego MC. 2001. Two early observations of aurora at low latitudes. Ann. Geophys. 19(7): 809-811.

Vaquero JM, Gallego MC. 2002. Evidence for a sunspot of A.D. 939 in an Arabian Source. Solar Phys. 206(1): 209-211.

Vernet J. 1982. Algunos fenómenos astronómicos observados bajo los omeyas españoles. Rev. Inst. Egip. Estud. Islám. XXI: 23-30.

Correspondence to: F. Domínguez-Castro f.dominguez.castro@gmail.com

(c) Royal Meteorological Society, 2012 DOI: 10.1002/wea.835 